\title{
EVALUATION OF ANTIULCEROGENIC ACTIVITY OF AQUEOUS EXTRACT OF Brassica oleracea var. capitata (CABBAGE) ON WISTAR RAT GASTRIC ULCERATION
}

\author{
Camilo Amaro de CARVALHO', Kenner Moraes FERNANDES ${ }^{1}$, Sérgio Luiz Pinto MATTA', \\ Marcelo Barreto da SILVA ${ }^{2}$, Leandro Licursi de LIVEIRA $^{1}$ and Cláudio César FONSECA ${ }^{1}$
}

\begin{abstract}
Context - The cabbage (Brassica oleraceae var. capitata) is an herbaceous and leafy plant which belongs to the Brassicaceae family, native to coastal southern and Western Europe. Used in cooking for its nutritional value also has known anti-inflammatory activity. Objective - We studied the antiulcerogenic activity of aqueous extract of Brassica oleracea var. capitata (AEB) in order to validate ethnobotanical claims regarding the plant use in the gastric disorders. Method - Acute gastric ulcers were induced in rats by the oral administration of acetylsalicylic acid. The gastroprotective potential of the AEB $\left(0.250,0.500 \mathrm{and} 1.000 \mathrm{mg} \cdot \mathrm{kg}^{-1} / \mathrm{body}\right.$ weight) was compared with omeprazole ( $20 \mathrm{mg} \cdot \mathrm{kg}^{-1} / \mathrm{body}$ weight). Results - The stomach analysis indicated that treatment with AEB inhibited the gastric damage. The gastroprotective activity as evidenced by its significant inhibition in the formation of ulcers induced by chemical agent with a maximum of $99.44 \%$ curation ( $250 \mathrm{mg} \cdot \mathrm{kg}^{-1}$ body weight) in acetylsalicylic acid-induced ulcers. Conclusions - The AEB demonstrated good antiulcerogenic activities which justify the inclusion of this plant in the management of gastric disorders. Further experiments are underway to determine which antiulcer mechanisms involved in gastroprotection.
\end{abstract}

HEADINGS - Anti-ulcer agents. Stomach ulcer. Brassica. Rats.

\section{INTRODUCTION}

The cabbage (Brassica oleraceae var. capitata) is an herbaceous and leafy plant which belongs to the Brassicaceae family, native to coastal southern and Western Europe. It presents a high versatility, not only due to its nutritive value, being rich in calcium, protein and vitamin $\mathrm{C}$, but also due to its social character, due to the fact of being cultivated essentially by smallscale farmers ${ }^{(12,28,29)}$

Brassica sp. is reported to have been utilized for over one thousand years in the healing process of abscesses, idiopathic cephalgias, internal ulcers; the Romans utilized Brassica sp. in the treatment of injuries ${ }^{(4)}$. Cheney ${ }^{(13)}$ verified that the patients who utilized the fresh cabbage juice obtained a healing action for gastric disorders, particularly for the peptic ulcer, presenting healing effects of the lesion.

The chronic administration of non-steroidal antiinflammatory drugs (NSAIDs) is associated with the development of gastrointestinal adverse effects, such as gastric erosions, gastritis or duodenum ulcers ${ }^{(8,24,34)}$. The etiological mechanism of these lesions involves ischemic processes with subsequent liberation of free radicals and the appearance of inflammatory infiltrate constituted mostly by neutrophils ${ }^{(6,8,32)}$.

The gastric mucosa exposed to ulcerogenic necrotizing agents such as the acetylsalicylic acid (ASA), indometacin, alcohol and ischemic, develops histopathological characteristics, ultrastructural and functional alterations which result in injuries ${ }^{(1,25,26)}$. Various selective agents for the cyclooxygenase-2, have been developed in order to minimize the adverse effects in the digestive tract, but these drugs are related to the decrease of prostaglandins concentrations, which are vital to the process of the mucosa tunic integrity maintenance, and gastric ulcer healing ${ }^{(8,11)}$.

The acute lesions of the gastric mucous membrane is associated with the rupture of the hydrophobic surface of the membrane; injury and exfoliation of the epithelium surface with loss of barrier and electrical function: deep injury of the mucosa layer, including vascular endothelial cells and cell proliferation zone. When there is damage to the vascular endothelium, a decrease of blood flow may occur, which reduces the oxygen supply and consequently the nutrients transport. All these events result in the appearance of erosion and ulceration in the mucous membrane.

\footnotetext{
Departamento de Biologia Geral, Universidade Federal de Viçosa - Viçosa, MG, Brasil; Departamento de Ciências Agrárias e Biológicas, Faculdade de Agronomia, Universidade Federal do Espírito Santo - São Mateus, ES, Brasil.

Correspondence: Dr. Camilo Amaro de Carvalho - Departamento de Biologia Geral da Universidade Federal de Viçosa - Avenida Peter Henry Rolfs s/n - $36570-000$ Viçosa, MG, Brasil. E-mail: camiloamaro@yahoo.com.br
} 
The difference between erosion and ulcer is that the erosion strikes the mucous layer, whereas the ulcer penetrates up to the muscle layer. The drugs currently utilized in the treatment of gastric ulcers are not totally efficacious in their healing ${ }^{(21,22)}$.

Phytotherapy constitutes a medical type of therapy which has been growing remarkably in the last years. In recent publications, many medicinal plants have been attested as useful in the treatment of gastric disorders ${ }^{(35)}$. The utilization of phytotherapy is supported, in many cases, by the traditional utilization by the populations, which would enable to justify its efficacy, necessary to emphasize the importance of pharmacological and toxicological researches which are essential to obtain confirmation of these implications, ensuring the safety of its utilization.

This work aimed at researching the pharmacological action of the aqueous extract of Brassica oleracea var. capitata (AEB), investigating its healing action in model of ulcer induced by non-steroidal anti-inflammatory drugs. This research provides a therapeutical alternative for treatment of gastric ulcers.

\section{METHODS}

\section{Botanical material}

The leaves of Brassica oleracea variety capitata (Brassicaceae) were obtained commercially. The material was washed, dried $\left(40^{\circ} \mathrm{C}\right)$ and was grained. The samples were solubilized in water in order to obtain an aqueous suspension. Subsequently, the suspensions were submitted to 60 minutes ultrasonication, in room temperature $\left(25^{\circ} \mathrm{C}\right)$, in order to extract its metabolites. All the extracts were vacuum filtered at $0.22 \mu \mathrm{m}$ sterile membrane and liofilizated.

\section{Animals}

Twenty-five male Wistar rats (Rattus norvergicus), adults (17 weeks), weighing 340 grams, and proceeding from the animal house of the Biological and Health Sciences Center of the Federal University of Viçosa (UFV), Viçosa, MG, Brazil were utilized. The animals were weighed and lodged in individual cages, constituting five trial groups, being maintained in conditions of controlled room humidity and temperature and in the light-dark cycle of 12 hours (07:0019:00) in the Laboratory of Animal Trial of the Nutrition Department. Water and food were made available ad libitum, being the food withdrawn 24 hours prior to the inducement of the ulcers, being the availability of water maintained.

The animals were manipulated in accordance with the Care and Utilization of Animals in Laboratories Manual( ${ }^{(2)}$ and in agreement with the Ethical Principles for the utilization of Animals in Laboratories recommended by COBEA - "Colégio Brasileiro de Experimentação Animal" and according recommendations guiding physicians in biomedical research involving human subjects - Declaration of Helsinki ${ }^{(33)}$, being approved by the Commission of Ethics of the Department of Veterinary of UFV, under protocol number 44/2008.

\section{Utilized drugs}

For the inducement of the lesions to the gastric mucous membrane, the non-steroidal anti-inflammatory ASA (400 $\mathrm{mg} . \mathrm{kg}^{-1}$, through oral administration) was utilized. The proton pump inhibitor omeprazole (OMP $-20 \mathrm{mg} \cdot \mathrm{kg}^{-1}$, oral administration) was administered to the control group.

\section{Evaluation of the AEB effects in the animals}

The animals were divided in five groups $(\mathrm{n}=5)$ (groups OMP, $\mathrm{AEB}_{1}, \mathrm{AEB}_{2}, \mathrm{AEB}_{3}$, and Mock) according to Table 1 , following the model described by Ajaikumar et al. ${ }^{(2)}$ with modifications by Berenguer et al. ${ }^{(8)}$ and Gonul et al. ${ }^{(16)}$. All the treatments have been carried out by gavage.

TABLE 1. Groups of animals and their respective oral administered treatments

\begin{tabular}{lc}
\hline Groups & Concentrations \\
\hline OMP & $20.0 \mathrm{mg} \cdot \mathrm{kg}^{-1}$ \\
$\mathrm{AEB}_{1}$ & $0.25 \mathrm{mg} \cdot \mathrm{kg}^{-1}$ \\
$\mathrm{AEB}_{2}$ & $0.50 \mathrm{mg} \cdot \mathrm{kg}^{-1}$ \\
$\mathrm{AEB}_{3}$ & $1.00 \mathrm{mg} \cdot \mathrm{kg}^{-1}$ \\
Mock & - \\
\hline
\end{tabular}

$\mathrm{AEB}=$ aqueous extract of Brassica oleracea var. capitata

$\mathrm{OMP}=$ omeprazole

Mock - only aqueous vehicle

For the procedure of inducement, the animals remained on an empty stomach diet for 24 hours, being given, afterwards, the ASA ( $400 \mathrm{mg} \cdot \mathrm{kg}^{-1}$, orally, dissolved in $\mathrm{HCl}$ $0,2 \mathrm{~N}$ ) in two doses, with interval of 12 hours between each administration, in a proportion of $1 \mathrm{~mL} \cdot 100^{-1} \mathrm{~g}$ of body weight. After 24 hours from the last dose of inducement of the lesion, all the animals were daily treated in accordance with the treatment corresponding to their group, for a period of 5 days. The group OMP received treatment with (20 mg. $\mathrm{kg}^{-1}$, orally), groups $\mathrm{AEB}_{1}, \mathrm{AEB}_{2}$ and $\mathrm{AEB}_{3}$ treatment with AEB in the concentrations of $0.250,0.500$ and $1.000 \mathrm{mg} . \mathrm{kg}^{-1}$, orally, respectively ${ }^{(5)}$, and Mock only aqueous vehicle. The animals were euthanized in the 6 th day after beginner treatments, through anesthetic overdose of sodium thiopental ( $60 \mathrm{mg} \cdot \mathrm{kg}^{-1}$ ) (Resolution 714 of the Federal Council of Veterinary Medicine $)^{(14)}$, for excision of the stomach and observation of the gastric lesions.

\section{Macroscopic evaluation of the gastric lesions}

After the removal of the stomach, an incision was made along the bigger curvature. The organ was washed with solution of $\mathrm{NaCl}(0.9 \%)$ for the removal of alimentary residues and subsequently fixed in neutral formalin solution at $10 \%$, for 24 hours. The organ was analyzed with stereomicroscope Olympus ${ }^{\circledR}$ SZ40, where fragments containing ulcerations were selected.

\section{Microscopic evaluation of the gastric lesions}

The selected fragments were fixed in 10\% neutral buffered formalin for 24 hours and embedded in paraffin $\left(56^{\circ} \mathrm{C}-58^{\circ} \mathrm{C}\right)$. Tissue sections $(5 \mathrm{~mm})\left(\right.$ Leica $\left.^{\circledR} 2045\right)$ were stained with 
hematoxylin and eosin $(\mathrm{H}-\mathrm{E})$ or Gomori trichrome ${ }^{(5)}$ to detect the ulcer structures using standard protocols. Samples were analyzed by light microscopy Olympus ${ }^{\circledR}$ BX 41 . The histological analysis was carried out in the Structural Biology Laboratory of the General Biology Department of UFV. Images were obtained in photomicroscopic Olympus ${ }^{\circledR} \mathrm{C} 31$, which were morphometrically analysed utilizing the Image-Pro Plus ${ }^{\circledR}$ (Media Cybernetics) program.

\section{Statistical analysis}

For the interpretation of the morphometric results, the presence of normality was verified through the Lilliefors test. After the normality was verified, the analysis of variance (ANOVA) was carried out to investigate possible differences among the researched groups, followed by the Tukey test at the level of $P \leq 0.05^{(27)}$. The statistical analyses were carried out with the software SAEG ${ }^{\circledR} 2007$.

\section{RESULTS AND DISCUSSION}

The results of the morphometric analysis allowed us to conclude that there was no significant statistical difference $(P>0.05)$ among the treatments with AEB and OMP (Table $2)$. However, a significant difference was verified among the control group treated with the vehicle, group Mock $(P<0.05)$, and the other treatments, as shown in Figure 1. Even though there was no statistical difference among the other treatments $\left(\mathrm{OMP}, \mathrm{AEB}_{1}, \mathrm{AEB}_{2}\right.$ and $\left.\mathrm{AEB}_{3}\right)$, the treatment $\mathrm{AEB}_{3}$ in absolute values, demonstrated to be more efficacious for obtaining a more improvement in the status of the lesions. These results allow the conclusion that the AEB may be equated to the OMP. However, in absolute numbers, the AEB $\left(B_{3}\right)$ presented about $95.77 \%$ more of decrease of the lesions, when compared to the group treated with OMP. It must be emphasized that cabbage is a greenery of easy culture and access, low cost and it does not present any apparent adverse effects. In addition, the AEB is not a particularly isolated substance, which leads us to deduce a possible superiority of the AEB in relation to the OMP.

Although the OMP provides optimum cicatrizating response to the ulcerated tissue due to its anti-secretor effect, it must be pointed out that there is a concern with its prolonged therapy, which is related to the achloride dependent bacterian growth in the upper digestive tube and the consequent superproduction

TABLE 2. Average area of the gastric ulcers in accordance with the treatments

\begin{tabular}{lcc}
\hline Treatments & Animals (n) & Average percentage (\%) lesions \\
\hline OMP & 5 & 13.18 \\
$\mathrm{AEB}_{1}$ & 5 & 6.73 \\
$\mathrm{AEB}_{2}$ & 5 & 15.07 \\
$\mathrm{AEB}_{3}$ & 5 & 0.56 \\
Mock & 5 & 100.00 \\
\hline
\end{tabular}

OMP = omeprazole

$\mathrm{AEB}=$ aqueous extract of Brassica oleracea var. capitata

Mock = only aqueous vehicle

*Averages followed of a same letter did not significantly differ by the Tukey test $(P \leq 0.05)$

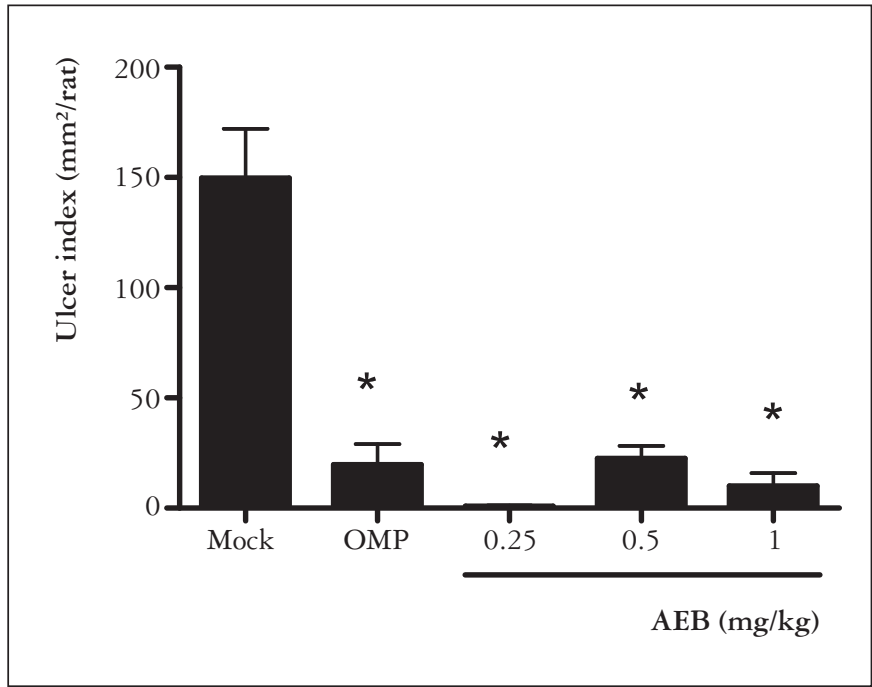

FIGURE 1. Percentage representation of the average values of the ulcerated area in the respective treatments: $\mathrm{OMP}=$ omeprazole, $\mathrm{AEB}(\mathrm{AEB}, \mathrm{AEB}$, and $\mathrm{AEB}_{3}$ ) and vehicle (Mock). $* P<0.01$ versus control group

of nitrites and, therefore, an eventual risk of gastric cancer. A hypergastrinemia was also observed in other researches carried out with rats, high incidence of carcinoid tumor and prolonged achloridry after the utilization of $\mathrm{OMP}^{(15)}$. This leads us to foresee that its clinical usage must be conducted with caution and under careful observation.

In this trial, the inducement model through NSAIDs provided a production of ulcers in the non-glandular region of the stomach of all the animals analysed, as shown in Figures 2A-B. A histopathological analysis was carried out in the glandular region, in order to confirm the absence of ulcerations in that region (Figures 2C-D). The glandular region of the gastric mucous membrane of the Wistar rats is less attacked by the formation of lesions, due to the protecting properties existing there, i.e., presence of mucus and bicarbonate produced by the epithelial surface cells, after a stimulating signal originated by the prostaglandins (PG's) ${ }^{(15,19)}$. These lipids are synthesized by the cyclooxygenases $(\mathrm{COX})$ and possess affinity by prostaglandin $\mathrm{EP}_{3}$ receptors in the basal portion of the surface epithelial cells of the gastric mucous membrane, leading to the liberation stimulus of the protecting factors ${ }^{(11)}$.

Dani and Castro ${ }^{(15)}$ reports that the phenomenon of the gastric lesion occurs when an aggression or decrease of resistance of the mucosa breaks the physiologic balance between the protection barriers and the ulcerogenic factors. According to Brunton et al. ${ }^{(11)}$ many factors are involved in the pathogenesis of the gastric ulcer. Among them we can mention the increase of hydrochloric acid, the decrease of the synthesis of prostaglandins which culminates in the decrease of the mucus secretion, in addition to the presence of the bacteria Helicobacter pylori.

The histopathological evaluation of the results (Figures $3 \mathrm{~A}-\mathrm{C}$ ) enabled to confirm the macroscopic observations previously effected. The gastric ulcers histologistically analysed consisted of two structures: the ulcer margin formed by the 

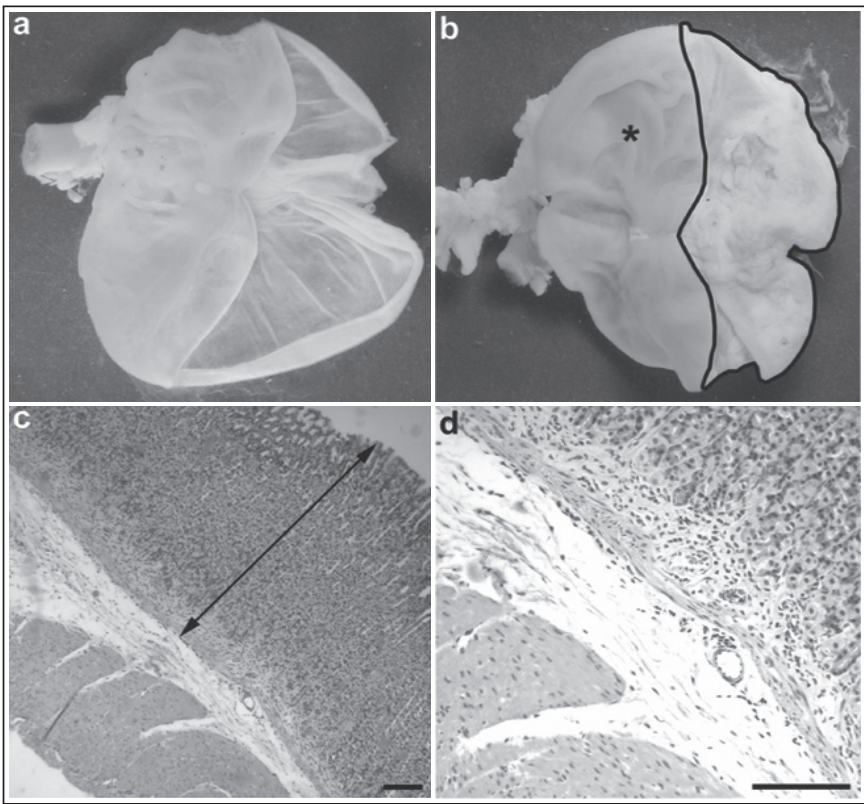

FIGURE 2. Anatomy and histopathology of the glandular region of the fundic mucosa of Wistar rats. Normal (a) and pathologic anatomy; (b) of the stomach of Wistar rats with ulcerations in the aglandular region (dotted area) - glandular region (*); (c-d) histopathology of the glandular region of the fundic mucosa of Wistar rats stomach, without ulcerations; intact mucosa in the gastric fundic region (double arrow); H-E (c) scale bar $100 \mu \mathrm{m}$ and (d) $150 \mu \mathrm{m}$

adjacent border not necrotized, delimiting the lesion area, and the base of the ulcer which is composed by necrotized tissue. A migration of the mucosa borders, cell proliferation, neovascularization and formation of granulation tissue were observed. In addition, the presence of mitotic figures in the ulcer base was observed, indicating reepithelization. The ulcers and erosions observed are characterized by intense inflammatory reaction with abundant granulation tissue, as well as, by intense proliferation of the fibrous connective tissue. According to Hawkey ${ }^{(19)}$, all these processes are controlled by cytokines and growth factors, including the transforming growth factor $\beta$, epidermal growth factor and fibroplast growing factors, and this is essential for the process of healing.

The inflammatory infiltratre was present in all the histological sections of the control group treated with vehicle, however it was found in a discrete shape in the histological sections of animals treated with the AEB and OMP (Figures 3A-C). Furthermore, a higher thickness of the gastric mucosa was observed in the animals of the group treated with AEB and OMP, when compared with the group treated only with vehicle.

When analysing the neovascularization, no significant statistical differences were observed among all the groups analysed. However the presence of ample vascularization of the connective tissue was verified in all the treatments (Figures 3D-E), a process of utmost importance at the moment of the reepithelization, thus favoring the healing process as described by Tarnawski et al. ${ }^{(31)}$.

The analysis of the preparations stained with Gomori trichrome enables us to deduce that there was proliferation of the collagen fibers of the deep portion in the ulcer base of the groups treated with AEB and OMP (Figures 3G-I). The collagen fibers were already organized and laid in parallel in the ulcer base. The control group Mock presented an evident inflammatory infiltrate and a delay in the synthesis of the collagen fibers when compared with the preparations of the groups treated with AEB and OMP. Similar results were obtained by Silva et al. ${ }^{(30)}$, when evaluating the cicatrizating effect of different phytotherapeutical formulations of the cabbage extract, in processes of healing of cutaneous wounds in Cavia cobaya.

The results of the healing of the gastric ulcers in this work are in accordance with those obtained in researches involving the species Brassica sp., where evaluating the healing potential of the cabbage juice for gastric ulcers, verified that it provided a high healing index after daily administration to his patients ${ }^{(13)}$. The compound obtained from the cabbage was denominated

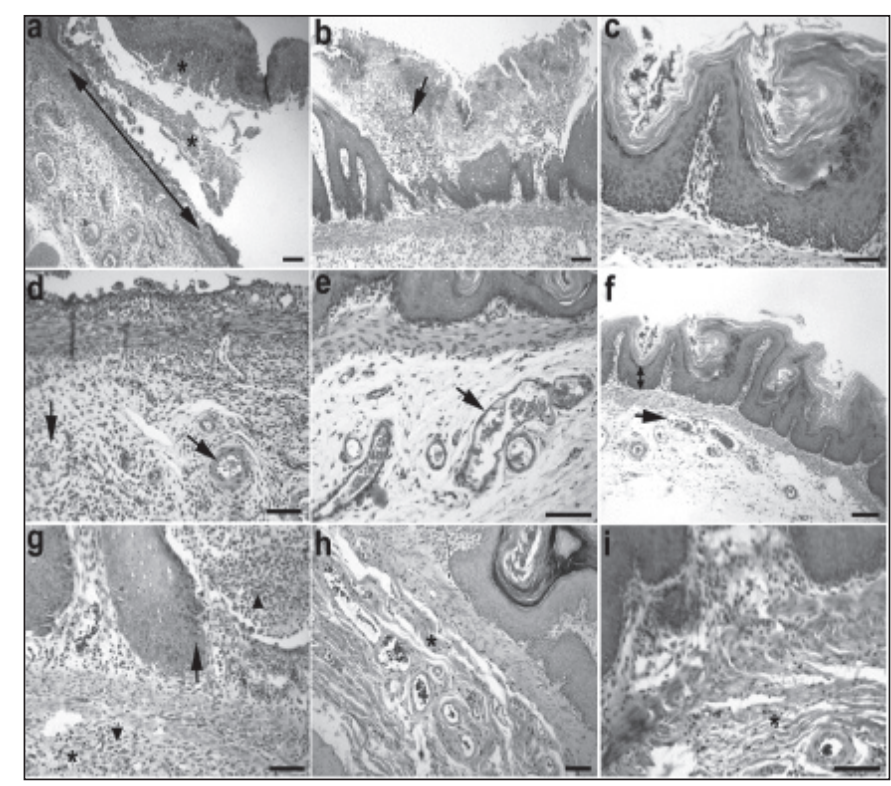

FIGURE 3. Effects of the treatments. (a-c) Lesions of the gastric mucosa of Wistar rats. (a) Mock; (b) OMP and (c) treated with AEB. Extension among the borders of the lesion (double arrow); inflammatory infiltrate and the product of tissue degradation (arrow); product of the tissue degradation detached from the mucosa due to the tissue fragility (*). (d-f) Effects of the treatments in the microcirculation of the gastric submucosa after the treatment. (d) Mock, administration of vehicle, (e) control group treated with OMP and (f) treatment with AEB. Congested vessels (arrows); epithelial residues $(*)$; reconstitution of the epithelial tissue lining with differentiation of its layers (double arrow). (g-i) Effects of the treatments in the proliferation of fibroblasts of the submucosa layer of the Wistar rats stomach after the treatment. (g) control group - Mock; (h) group treated with OMP and (i) group treated with AEB. Collagen fibers of the connective tissue $(*)$; inflammatory infiltrate (arrow tip); epithelium migrating from the borders of the ulcer margins (arrow). a-f H-E; g-i Gomori trichrome. Scale bars (a-d) and (f-i) $150 \mu \mathrm{m}$; (e) scale bar $100 \mu \mathrm{m}$ 


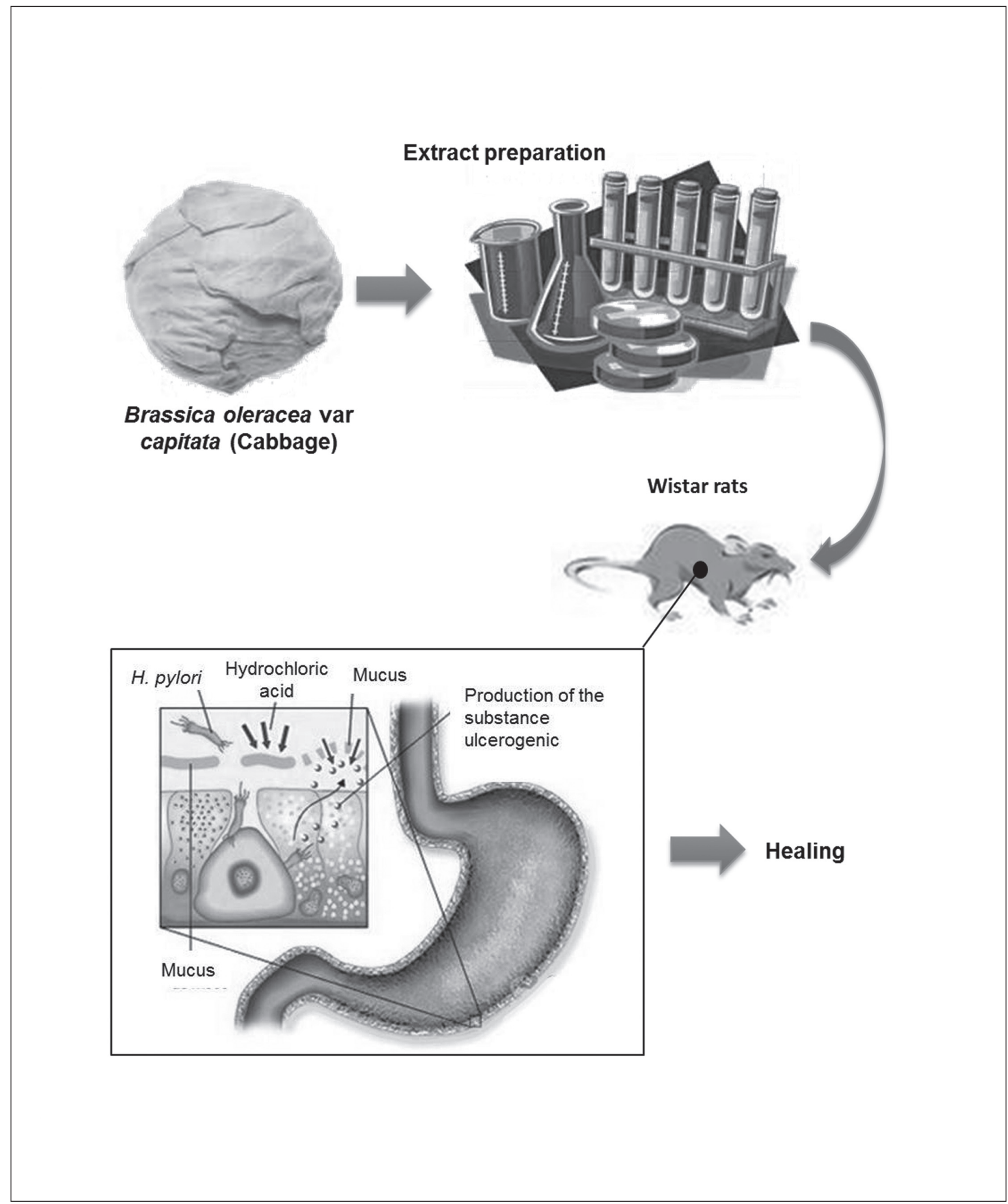

FIGURE 4. Antiulcerogenic activity of aqueous extract of Brassica oleracea var. capitata (cabbage) on Wistar rat gastric ulceration 
methionine sulfonium chloride (S-Methylmethionine), related with the healing action and then called "unknown vitamin" or ulcer vitamin and supposedly the term vitamin $U$ was suggested.

Our results are also in accordance with those obtained by Gonzalez et al. ${ }^{(17)}$, who concluded that the flavonoids may be recognized as active compounds against gastric lesions. In previous researches, carried out by Carvalho et al. ${ }^{(12)}$, the presence of these secondary metabolites was verified, as well as the presence of phenolic compounds, triterpenes and steroids. Alcaraz et al. ${ }^{(3)}$ verified that the secondary metabolites revealed gastroprotecting action by increase of the prostaglandins grade in the mucosa. Reduction of the secretion of histamine by the inhibition of the histidine descarboxylase enzyme and inhibition of the development of the Helicobacter pylori was also verified $^{(7,10,18)}$.

The compounds obtained from medicinal plants with cicatrizating and antiulcerogenic action presented diverse chemical structures and distinct mechanisms of action. The mechanisms of action of the AEB are not yet clear, but might involve the activation of gastric mucosa protection factors, as well as the reduction of the acid secretion and of pepsinogen, besides the increase of the gastric blood flow, mucus and bicarbonate ${ }^{(9)}$. However these data are of utmost importance, as they enable their correlation with the cicatrizating effect of the extract analysed.

It can be verified that the results are similar to those presented in the literature and with other researches previously carried out, thus confirming the therapeutical effects of Brassica oleracea variety capitata, in the form of aqueous extract, for the cicatraization of gastric ulcers in Wistar rats (Figure 4). The plant under reference has proven an interesting research target, aiming the development of phytomedicaments or the search of new chemical entities with cicatrizating action for the gastric ulcer. It is known that this pharmaco action is intimately related to its concentration and its coefficient of action in the vehicle ${ }^{(24)}$. However, additional researches are necessary to analyse its therapeutical effect, as tests must be carried out utilizing higher concentrations of the extract, and simultaneously verifying the toxicity on the organism, besides testing the extract under other ways of administration and pharmaceutical formulations.

\section{CONCLUSIONS}

It was concluded that the aqueous extract of Brassica oleracea variety capitata provided the healing of gastric ulcers of Wistar rats. The result obtained with the AEB was similar to that of a commonly commercialized pharmaco, the OMP, acting in a non harmful manner and, to the contrary, providing adequate conditions for the tissue recuperation.

\section{ACKNOWLEDGMENTS}

We thank Alex B. Cardoso for technical support. This work was supported by Fundação de Amparo à Pesquisa do Estado de Minas Gerais (FAPEMIG), and Conselho Nacional de Desenvolvimento Científico e Tecnológico (CNPq) grants.

Carvalho CA, Fernandes KM, Matta SLP, Silva MB, Oliveira LL, Fonseca CC. Avaliação da atividade antiúlcera do extrato aquoso de Brassica oleracea var. capitata (repolho) em úlceras gástricas de ratos Wistar. Arq Gastroenterol. 2011;48(4):276-82.

RESUMO - Contexto - O repolho (Brassica oleracea var. capitata) é uma planta de folhas herbáceas pertencente à família Brassicaceae, nativa na costa sul e oeste da Europa. Usado na culinária por seu valor nutritivo, possui conhecida atividade anti-inflamatória. Objetivo - Avaliar a atividade antiulcerogênica do extrato aquoso de Brassica oleracea var. capitata (AEB), a fim de validar os conhecimentos etnobotânico do uso da espécie em distúrbios gástricos. Método - Úlceras gástricas foram induzidas em ratos pela administração oral de ácido acetilsalicílico. O potencial gastroprotetor de AEB $(0,250,0,500$ e 1,000 mg. $\left.\mathrm{kg}^{-1} / \mathrm{peso}\right)$ foram comparados com omeprazol (20 mg.kg-1/peso). Resultados - As análises dos estômagos indicaram que o tratamento com AEB inibiu a progressão da lesão gástrica. A atividade gastroprotetora foi evidenciada por sua significativa inibição da progressão da úlcera induzida por agentes químicos, com o máximo de $99,44 \%$ eficácia ( $\left.250 \mathrm{mg} \cdot \mathrm{kg}^{-1} / \mathrm{peso}\right)$ frente a úlceras gástricas induzidas por ácido acetilsalicílico. Conclusões - O AEB demonstrou atividade cicatrizante de úlceras gástricas, o que justifica a inclusão da espécie em tratamentos de distúrbios gástricos. Estudos futuros estão em andamento para determinar quais os mecanismos antiulcerogêncios estão envolvidos com a gastroproteção.

DESCRITORES - Antiulcerosos. Úlcera gástrica. Brassica. Ratos.

\section{REFERENCES}

1. Aguwa $\mathrm{CN}$. Incidence of gastric ulcers by indomethacin and piroxicam in rats Arch Toxicol. 1985;56:212-3

2. Ajaikumar KB, Asheef M, Babu BH, Padikkala J. The inhibition of gastric mucosal injury by Punicagranatum L. (pomegranate) methanolic extract. J Ethnopharmacol. 2005;96:171-6.

3. Alcaraz MJ, Hoult JR. Effects of hypolaetin-8-glucoside and related flavonoids on soybean lipoxygenase and snake venom phospholipase A2. Arch Int Pharmacodyn Ther. 1985;278:4-12.

4. Balbach A, Boarim DSF. As hortaliças na medicina natural. $2^{\mathrm{a}}$ ed. Itaquaquecetuba: Vida Plena; 1992. p.292.

5. Bancroft JD, Stevens A. Theory and practice of histological techniques. 4th ed. New York: Churchill Livingstone; 1996.
6. Beck PL, Xavier R, Lu N, Nanda NN, Dinauer M, Podolsky DK, Seed B. Mechanisms of NSAID-induced gastrointestinal injury defined using mutant mice. Gastroenterology. 2000;119:699-705

7. Beil W, Birkholz C, Sewing KF. Effects of flavonoids on parietal cell acid secretion, gastric mucosal prostaglandin production and Helicobacter pylori growth. Arzneimittelforschung. 1995;45:697-700.

8. Berenguer B, Alarcón de la Lastra C, Moreno FJ, Martín MJ. Chronic gastric ulcer healing in rats subjected to selective and non-selective cyclooxygenase-2 inhibitors. Eur J Pharmacol. 2002;442:125-35.

9. Borrelli F, Izzo AA. The plant kingdom as a source of anti-ulcer remedies. Phytother Res. 2000;14:581-91.

10. Bronner C, Landry Y. Kinetics of the inhibitory effect of flavonoids on histamine secretion from mast cells. Agents Actions. 1985;16:147-51.

11. Brunton LL, Lazo JS, Parker KL, editors. Goodman \& Gilman's the pharmacological basis of therapeutics. 11th ed. New York: McGraw Hill; 2007. 
12. Carvalho CA, Silva MB, Oliveira TG, Lima JM, Rosa MB. Spectrometric study at different phenologic stages of the cabbage (Brassica oleraceae var. capitata). Rev Bras Farmacogn. 2008;18:249-57.

13. Cheney G. Vitamin U therapy of peptic ulcer. Calif Med. 1952;77:248-52.

14. Conselho Federal de Medicina Veterinária. Resolução n. 714 de 20 de junho de 2002. Dispõe sobre procedimento de eutanásia em animais e dá outras providências. Diário Oficial da União, Brasilia, DF., 21 de junho de 2002.

15. Dani R, Castro LP, editores. Gastroenterologia clínica. $3^{\mathrm{a}}$ ed. Rio de Janeiro: Guanabara Koogan; 1993.

16. Gonul B, Akbulut KG, Ozer C, Yetkin G, Celebi N. The role of transforming growth factor alpha formulation on aspirin-induced ulcer healing and oxidant stress in the gastric mucosa. Surg Today. 2004;34:1035-40.

17. Gonzalez FG, Di Stasi LC. Anti-ulcerogenic and analgesic activities of the leaves of Wilbrandia ebracteata in mice. Phytomedicine. 2002;9:125-34.

18. Havsteen BH. The biochemistry and medical significance of the flavonoids. Pharmacol Ther. 2002;96:67-202.

19. Hawkey CJ. Nonsteroidal anti-inflammatory drug gastropathy. Gastroenterology. 2000;119:521-35.

20. Institute of Laboratory Animal Resources. Commission on Life Sciences. National Research Council. Manual sobre cuidados e usos de animais de laboratório. Goiânia: AAALAC e COBEA; 2003.

21. Jones NL, Day AS, Sherman PM. Determinants of disease outcome following Helicobacter pylori infection in children. Can J Gastroenterol. 1999;13:613-17.

22. Jones NL, Sherman PM. Helicobacter pylori-epithelial cell interactions: from adhesion to apoptosis. Can J Gastroenterol. 1999;13:563-6.

23. Jones RH, Tait CL. Gastrointestinal side-effects of NSAIDs in the community. Br J Clin Pract. 1995;49:67-70.

24. Lachman L, Lieberman HA, Kaning JL. Teoria e prática na indústria farmacêutica. $5^{\mathrm{a}}$ ed. Lisboa: Fundação Calouste Gulbenkian; 2001.
25. Popovic M, Janicijevic-Hudomal S, Kaurinovic B, Rasic J, Trivic S. Antioxidant effects of some drugs on ethanol-induced ulcers. Molecules. 2009;14:816-26.

26. Scheiman J, Herlitz J, Devereaux P, Naucler E, Erik L. Low-dose acetylsalicylic acid-associated peptic ulcers and dyspeptic symptoms are reduced by esomeprazole $20 \mathrm{mg}$ and $40 \mathrm{mg}$ once daily. Am Coll Cardiol. 2010;55.

27. Siegel S, Castellan JRNJ. Nonparametric statistics for the behavioral sciences. New York: McGraw-Hill; 1988. 399p.

28. Silva Jr AA, Miura L, Yokoyama S. Repolho: novas cultivares de verão. Agrop Catarinense. 1988;1(3):47-9.

29. Silva Jr AA. Repolho: fitologia, fitotecnia, tecnologia alimentar e mercadológica. Florianópolis: EMPASC; 1989.

30. Silva MB, Silva CA, Malaquias LCC, Sarandy MM, Freire MCM, Antunes, FR, Costa AVS. Comparative effect of a phytotherapeutic product from Brassica ssp as cicatrizing. Rev Bras Pl Med. 2006;8:136-8.

31. Tarnawski A, Douglass TG, Stachura J, Krause WJ. Quality of gastric ulcer healing: histological and ultrastructural assessment. Aliment Pharmacol Ther. 1991;5:79-90.

32. Villegas I, Martín MJ, La Casa C, Motilva V, Alarcón de la Lastra C Effects of meloxicam on oxygen radical generation in rat gastric mucosa. Inflamm Res. 2000;49:361-6.

33. World Medical Association declaration of Helsinki. Recommendation guiding physicians in biomedical research involving human subjects. JAMA. 1997;277:922-3

34. Wright V. Historical overview of non-steroidal anti-inflammatory drugs. Br J Rheumatol. 1995;34:2-4.

35. Yunes RA, Pedrosa RC, Cechinel Filho V. Pharmaceutics and phytotherapics: the need for development of the industry of phytopharmaceutics and phytotherapics in Brazil. Quím Nova. 2001;24:147-52. 